УДК 378.04:615.8(4/9)

(C) Фастівець А. В., 2021 p.

http://orcid.org./0000 - $0002-5985-8293$

DOI: $10.34142 / 23128046.2021 .51 .15$

А. В. Фастівець

\title{
СВІТОВИЙ ДОСВІД ПІДГОТОВКИ ФАХІВЦІВ ФІЗІОТЕРАПІЇ ТА ЕРГОТЕРАПІї
}

Сучасний світовий простір характеризується глобальним зниженням рівня здоров'я населення, внаслідок чого актуалізується потреба $у$ кваліфікованих фахівиях, здатних розробляти та застосовувати новітні комплексні реабілітаційні технології, що, зі свого боку, зумовлює вивчення різних аспектів професійної підготовки фахівиів із фізичної реабілітації в зарубіжних країнах для розвитку галузі фізичної терапії й ерготерапї в Украӥні. Метою статті $\epsilon$ аналіз світового досвіду підготовки фахівиів фізіотерапії та ерготерапіï.

Для досягнення мети було використано комплекс методів дослідження, зокрема, теоретичних: аналіз $i$ синтез наукової та науково-методичної літератури, методичних документів; спостереження, опис, порівняння; узагальнення та систематизачія результатів наукових досліджень; синтез наукових теорій, підходів, конщепцій. Автором проведено аналіз світового досвіду підготовки фахівиів фізіотерапії й ерготерапії. На основі узагальнення даних аналізу зарубіжного досвіду з'ясовано, що спеціальності, за якими сьогодні здійснюється підготовка фахівців з фізичної реабілітації, $\epsilon$ парамедичними й належать до галузі охорони здоров'я.

Встановлено, щу назви изих спеціальностей відрізняються в різних краӥнах (фізична терапія, фізіотерапія, реабілітація тощо), однак основним спрямуванням професійної діяльності фахівиів у галузі фізичної реабілітації $\epsilon$ відновлення рухових функиій в осіб різних нозологій та різних категорій населення за допомогою фізичних засобів і методів. Виявлено, що сфера професійної спрямованості фахівиів з фізичної терапії також передбачає консультативну, дослідницьку й викладацьку діяльності. Визначено провідні тенденції підготовки фахівців із фізичної терапї в зарубіжних країнах, які суттево відрізняються від системи підготовки фахівиів цього профілю в Україні. Зазначені відмінності можуть бути методичним орієнтиром для модернізації професійної підготовки фізіотерапевтів та ерготерапевтів у закладах вищої освіти Украӥни.

Ключові слова: фізична терапія, прачетерапія, система підготовки фахівиів, освітній прочес, компетентні фахівиі, навчальні програми.

Fastivets A. V. Physiotherapy and ergotherapy specialists training global experience. In the era of globalization recession of health level of population in 
Ukraine the demand for qualified specialists able to develop and use new complex rehabilitation technologies grows. That is why the study of different aspects of physical rehabilitation specialist professional training in foreign countries is to be a boon for the development in the field of physical therapy and ergotherapy in Ukraine. The article is aimed at the analysis of global experience of physiotherapy and ergotherapy specialists training.

To secure the object the complex of research methods was used, including theoretical methods: analysis and аналіз of scientific and methodical literature, methodical documents; observation, description, comparison; generalization and systematization of research results; synthesis of scientific theories, approaches and conceptions. The analysis of global experience of physiotherapy and ergotherapy specialist professional training is done. Generalization of global experience analysis data showed that the modern physical rehabilitation specialists training specialties are paramedical and belong to the branch of health care.

It is proved that he titles of these specialties differ from the titles in other countries (physical therapy, physiotherapy, rehabilitation, etc.), but the principal direction of professional work of physical rehabilitation specialists is the motor function recovery of people with different ICD diseases and different population categories using physical means and methods. The field of professional orientation of physical therapy specialists includes advisory, research and education work. Analysis and generalization of research results allowed defining the main trends in physical therapy specialists training in foreign countries which differ much from the system of physical rehabilitation specialists training in Ukraine. The above mentioned differences may become the methodic focus for modernization of professional training of physiotherapists and ergotherapists in Ukrainian higher educational institutions.

Keywords: physical therapy, occupational therapy, specialists training system, educational process, competent specialists, academic programs.

Вступ. Життя і здоров'я людини є найважливішою соціальною цінністю сучасної цивілізації. Суспільна потреба в збереженні, відновленні та зміцненні здоров'я населення, а також бажання громадян нашої країни бути здоровими, породжує попит на фахівців, які здатні коригувати психофізіологічний стан людини з використанням не тільки медичних засобів, а й засобів фізичної культури. Такий вплив значно прискорює одужання й забезпечує максимально можливе відновлення втрачених функцій, а також підтримання та підвищення рівня здоров'я населення.

Саме тому галузь фізичної терапії стрімко розвивається на теренах України, що, в свою чергу, визначає наявність потреби у фахівцях із відповідної спеціальності. Водночас, сучасні тенденції розвитку медичної галузі та фізичної терапії в Україні позначені помірними успіхами в становленні реабілітаційного напряму, головним спрямуванням якого визначено поетапне, відновне комплексне лікування патологічних процесів, захворювань й ушкоджень 
організму людини. На окрему увагу заслуговує дослідження проблеми системи професійної підготовки фахівців зі спеціальності «Фізична терапія, ерготерапія», що потребує аналізу досвіду такої підготовки в закладах вищої освіти країн Європи та світу загалом, що, зі свого боку, дасть змогу оптимізувати розвиток галузі в Україні.

Реалізація позитивних тенденцій в українській системі вищої освіти потребує всебічного вивчення закордонного досвіду підготовки фахівців із фізичної терапії, що вимагає критичного аналізу здобутків закордонних освітніх систем та адаптації їхніх напрацювань до українських потреб. Незважаючи на значення проведених наукових пошуків окресленого питання, проблема аналізу світового досвіду підготовки фахівців фізіотерапії та ерготерапії залишається недостатньо дослідженою в теоретико-методологічному аспекті.

Аналіз науково-методичної і спеціальної літератури свідчить, що питання підготовки фізичних терапевтів та ерготерапевтів у зарубіжних країнах розглядали: Ю. Лянной - особливості підготовки бакалаврів та магістрів в університетах США, Австрії, Данії, Канаді (Liannoi, 2015, 2017); Н. Бєлікова основні аспекти професійної підготовки майбутніх фахівців 3 фізичної реабілітації у Польщі (Bielikova, 2010); А. Герцик - підготовка бакалаврів із фізичної реабілітації в Канаді (Hertsyk, 2004, 2010); С. Гук (Huk, 2015), I. Мордвінова, А. Ольховик (Mordvinova, Olkhovyk, 2018), Ю. Копочинська (Kopochynska, 2020) - зміст професійної підготовки майбутніх фахівців 3 фізичної терапії у Великій Британії; О. Базильчук - навчальну програму підготовки фахівців із фізичної терапії в закладах вищої освіти Ізраїлю (Bazylchuk, 2017, 2019). Проте на сьогодні в українській науці мало досліджень, які пов'язані з вивченням досвіду професійної підготовки бакалаврів і магістрів iз фізичної терапії у зарубіжних країнах. Тому пропонована проблематика $\epsilon$ актуальною для підвищення рівня професійної підготовки фахівців із фізичної терапії та ерготерапії в Україні.

Мета та завдання. Мета статті полягає в аналізі світового досвіду підготовки фахівців фізіотерапії й ерготерапії. Відповідно до мети було поставлено такі завдання: на основі аналізу наукових джерел дослідити специфіку і визначити провідні тенденції професійної підготовки фахівців із фізичної терапії та ерготерапії у зарубіжних країнах; обгрунтувати перспективні шляхи творчого впровадження прогресивних ідей зарубіжного досвіду в заклади вищої освіти України; виявити типові риси системи професійної підготовки майбутніх фахівців, які суттєво відрізняються від української; провести компаративний аналіз навчальних планів у досліджуваних країнах.

Методи дослідження. Для визначення тенденцій професійної підготовки фізичних терапевтів та ерготерапевтів використано такі методи: спостереження, 
опис, порівняння й узагальнення. 3 метою виокремлення головних періодів еволюції системи професійної підготовки майбутніх фахівців у закладах освіти різних країн нами було використано ретроспективний аналіз; задля визначення основних принципів та закономірностей здійснення професійної підготовки фахівців використано такі методи: аналіз, синтез, індукцію, дедукцію, класифікацію, систематизацію, узагальнення та типологізацію. Загальнонауковий аналіз автором використано в процесі опрацювання різноманітних наукових джерел і нормативно-правових актів, що регламентують освітню діяльність закладів вищої освіти; структурно-функціональний аналіз використано з метою виділення досліджуваних складників соціальної взаємодії, визначення їх місця та значення у процесі підготовки висококваліфікованих фахівців із фізичної терапії.

Результати. Для здійснення цілісного аналізу зарубіжного досвіду передусім необхідно визначити різницю між двома термінами - «фізична терапія» та «ерготерапія» (Hertsyk, 2010). Відповідно до тлумачення Польського товариства фізіотерапї (Polskie towarzystvo zjoterapii), «фізична терапія» $\mathrm{\epsilon}$ повним або частковим відновленням функцій організмів людей з особливими потребами шляхом застосування фізичних вправ із лікувальною метою (Polskie towarzystvo zjoterapii) (Hertsyk, 2010). Водночас, у дослідженнях фахівців Канадської асоціації фізичної терапії (Canadian Physiotherapy Association) зустрічаємо таке тлумачення поняття: «фізична терапія - це професійна галузь охорони здоров'я, спрямована на запобігання та максимально можливе зменшення рухових дисфункцій (насамперед, шляхом застосування фізичних вправ)» (Hertsyk, 2010; Fastivets, Khomenko \& Shaparenko, 2018).

Як засвідчує аналіз праць Н. Бєлікової й А. Герцика, система професійної підготовки майбутніх фізичних терапевтів у Болгарії існує в трьох університетах i трьох вищих коледжах, які щорічно випускають близько 200 фахівців із фізичної терапії. Згідно з офіційними даними департаменту освіти Болгарської асоціації кінезіотерапевтів та реабілітологів (Bulgarian Association of Kinesitherapists and Rehabilitators), університетська підготовка фізичних терапевтів в країні триває чотири роки (3750 навчальних годин), а в коледжах три роки (3900 навчальних годин).

Після завершення трирічного терміну навчання випускники здобувають ступінь бакалавра 3 фізичної терапії (BSc in Physiotherapy) i кваліфікацію реабілітолога (Rehabilitator). Після завершення чотирирічного терміну підготовки студенти університетів отримують професійну кваліфікацію кінезітерапевта (Kinesitherapist). Усі фізіотерапевти в Болгарії підпорядковуються Міністерству охорони здоров’я (Bielikova, 2010; Hertsyk, 2010). 
Системою вищої освіти Португалії передбачено чотирирічний термін підготовки фахівців у галузі фізіотерапії, що відповідає 2945 навчальним годинам, з яких 860 годин відведено на теоретичне навчання, 515 - на практичне, 570 - на клінічне, 20 - на семінари та 980 - на стажування. Тривалість підготовки магістрів із фізичної терапії становить три семестри й передбачає введення кардіореспіраторної, соціальної, ортопедичної, мануальної, спортивної й неврологічної реабілітації у спеціалізацію майбутніх фахівців (Bielikova, 2010).

Професійна підготовка фахівців із фізичної терапії у Великій Британії сьогодні здійснюється за двома освітніми рівнями: бакалавр (термін підготовки складає 3 роки), магістр (із терміном навчання 1-2 роки). Також варто зазначити, що тривалість навчального року в закладах вищої освіти Великої Британії становить 9 місяців (із кінця вересня до кінця червня) (Mordvinova \& Olkhovyk, 2018; Huk, 2015). Трирічна програма навчання майбутніх фахівців із фізичної терапії за освітнім рівнем «Бакалавр» у британських закладах вищої освіти зорієнтована на роботу із населенням, що передбачає максимізацію функціональних можливостей і потенціалу пацієнтів.

Зміст курсу професійної підготовки фізіотерапевтів у закладах вищої освіти Великої Британії спрямований на вивчення функціональних систем організму людини та їхнього впливу на здатність організму рухатися й ефективно функціонувати. Основну увагу зосереджено на нервово-м'язовій, опорно-руховій, серцево-судинній і респіраторній терапії в умовах гострої або хронічної стадії перебігу захворювань. Під час навчання у закладах вищої освіти майбутні фахівці співпрацюють зі здобувачами освіти з інших спеціальностей, які є суміжними 3 фізичною терапією. Так, досвід міжпрофесійної роботи у команді є базовим елементом професійної діяльності фізіотерапевтів (Kopochynska, 2020).

Програма першого курсу підготовки фахівців передбачає вивчення п'яти обов'язкових модулів: «Основи професійної практики» («Foundations of professional practice»), «Науки про людину» («Human Sciences»), «Теорія й практика фізичної терапії («Physiotherapy theory and practice»), «Міжпрофесійне навчання - рівень 1» («Interprofessional learning - Level 1»), «Обов’язкове навчання» («Mandatory training») i «Навчальна практика» («Practice education»). 3 позиції завдань авторського дослідження важливим вважаємо зосередити свою увагу на модулі «Науки про людину» («Human Sciences»), який є інтегрованим циклом природничо-наукових дисциплін, спрямованим на ознайомлення студентів із теоретичними основами клінічних наук. У цьому курсі пропонується вивчення біопсихосоціальних процесів, які лежать в основі функціонування організму людини. 
У процесі теоретичної й практичної роботи здобувачів освіти розглядаються основні анатомічні, фізіологічні, психологічні й соціологічні процеси, які мають враховуватися в практичній діяльності фізіотерапевта, а результати вивчення дисциплін $є$ підгрунтям для вивчення модулів професійної практики у сфері ерготерапії та фізіотерапії.

Програма другого курсу навчання передбачає вивчення таких обов'язкових модулів: «Практика на основі досвіду» («Evidence based practice»), «Обов’язкове навчання» («Mandatory training»), «Теорія й практика фізичної терапії» («Physiotherapy theory and practice»), «Навчальна практика» («Practice education»). Модулі, що вивчаються на третьому курсі професійної підготовки, включають: «Контекст практики» («Context of practice»), «Фізіотерапевтичну практику» («Physiotherapy practice»), «Додаткову освіту» («Placement education»), «Професійний розвиток» («Professional development») (Kopochynska, 2020).

Заклади вищої освіти Великої Британії активно підтримують інноваційні підходи до розробки і використання програм професійної підготовки фахівців у навчальному процесі. Водночас, як слушно стверджують фахівці, характер здійснення освітнього процесу в межах індивідуальних освітніх програм завжди залежить виключно від закладів вищої освіти (Kopochynska, 2020). Навчальний процес в університетах і практична підготовка на базах практик грунтуються на принципі поєднання теорії та практики.

Вивчення інформаційних ресурсів мережі Інтернет дало змогу встановити, що на території Польщі підготовку майбутніх фахівців із фізичної терапії (реабілітації) здійснюють різні типи закладів вищої освіти, зокрема академії фізичного виховання, медичні заклади вищої освіти, державні університети й коледжі. Разом з тим, перший цикл професійної підготовки, зазвичай, триває 3 3,5 роки, а після його завершення випускникам присвоюється ступінь бакалавра 3 фізіотерапії. Здобувачі, які продовжують навчання, мають змогу здобути ступінь магістра, який присвоюється їм після завершення 5-6-річного терміну професійної підготовки в університеті або після завершення додаткового навчання на здобуття ступеня магістра, тривалість якого складає 2-2,5 роки (Bielikova, 2010).

У документах Польського товариства фізіотерапії вказано, що фахівець із фізичної терапії здійснює свою професійну діяльність у сфері охорони здоров'я на основі професійного партнерства 3 лікарем, що $є$ фахівцем із медичної реабілітації. Головним його завданням $є$ здійснення діагностичних тестів для формування рекомендацій щодо застосування тренувальних програм та особистий контроль їх виконання. Разом з тим є певні проблеми, що стосуються регуляції професійного статусу фізіотерапевтів, який повинен чітко визначати 
компетенції, професійні знання, уміння, навички й норми професійної етики фахівця в зазначеній галузі.

Професійний статус фізичного терапевта в Польщі належить до сфери охорони здоров'я та медичних професій. Варто зазначити, що професійна підготовка таких фахівців у польських закладах вищої освіти здійснюється згідно з Державним освітнім стандартом за напрямом підготовки «Фізіотерапія» (Standardy kształcenia dla kierunku studiów: Fizjoterapia). У цьому документі зазначено, що для отримання кваліфікації бакалавра з фізичної терапії тривалість навчання повинна складати не менше шести семестрів, загальна кількість навчальних годин має досягати не менше 2900, а кількість кредитів ECTS - бути не меншою від 180 (Bielikova, 2010).

Порівняльний аналіз навчальних планів засвідчує, що цикл фундаментальних дисциплін у закладах вищої освіти Польщі становить майже 17 \% від загального обсягу навчального часу. Варто зазначити, що в Україні цей показник у різних ЗВО коливається від $19 \%$ до $23 \%$. Обсяг дисциплін професійно-практичного циклу в польських закладах, що здійснюють підготовку фахівців із фізіотерапії, становить майже 42 \% (в Україні - 50 \%). Перелік фундаментальних дисциплін здебільшого збігається з тим, який маємо в Україні. Перелік дисциплін професійного спрямування значно відрізняється від українського наявністю великої кількості клінічних дисциплін. Окрім цього, всі практики мають клінічне спрямування: клінічна практика; практика в лабораторії фізіотерапії; практика в лабораторії кінезітерапії; клінічна практика у фізичній терапії (Osvitni standarty № 33. Fizioterapiia, 2021).

Цикл фундаментальних дисциплін у польських закладах освіти передбачає вивчення таких предметів: генетика, фармакологія, методологія досліджень, історія реабілітації, філософія, біоетика, спеціальна педагогіка, соціологія неповносправних та їхня реабілітація, викладання фізичної терапії, демографія i епідеміологія, охорона здоров'я, економіка в галузі охорони здоров'я, менеджмент і маркетинг. До циклу дисциплін професійного спрямування віднесено такі дисципліни: спеціальні методи фізичної терапії, фізична медицина і бальнеокліматологія, функціональна діагностика і програмування реабілітації, протезування і ортопедія, адаптивна фізична активність, спорт для інвалідів (Osvitni standarty № 33. Fizioterapiia, 2021).

У дослідженнях О. Базильчука зазначено, що навчальна програма підготовки фахівців із фізичної терапії в закладах вищої освіти Ізраїлю побудована за такою логікою: дисципліни першого року навчання спрямовані на вивчення фундаментальних наук (хімії, анатомії, біомеханіки, фізіології), які закладають природничо-наукові основи професії фізіотерапевта. Окрім того, перший рік навчання передбачає вивчення курсів соціально-гуманітарного 
спрямування - соціологія здоров'я, психологія, основи статистики, методи дослідження.

Також перший рік навчання містить низку практичних курсів професійного спрямування: випробування i вимірювання, лікувальний масаж, мануальна терапія, що загалом становлять 59,5 кредитів ECTS. Фокус другого року навчання передбачає орієнтацію навчальних планів на вивчення суто медичних дисциплін загальним обсягом 59 кредитів - наукові основи фізіотерапії, патологія, захворювання різних систем організму, хірургічні процедури.

Третій рік навчання зорієнтований на вивчення дисциплін, що обгрунтовують методи фізичної реабілітації різних вікових та соціальних груп, загальним обсягом 55 кредитів ECTS. Четвертий рік підготовки, загальний обсяг якого складає 35,5 кредитів ECTS, зорієнтований на набуття практичного клінічного досвіду й містить інтегровані курси 3 розвитку професійних та адміністративних якостей. Як зазначає О. Базильчук, загальний обсяг чотирирічного навчального навантаження становить 209 кредитів ECTS, а після завершення навчання фахівці мають отримати ліцензію в Міністерстві охорони здоров’ я Ізраїлю.

Так, підготовка майбутніх реабілітологів (фізіотерапевтів) у системі вищої освіти Ізраїлю характеризується типовими рисами, які суттєво відрізняють цю систему від української: розробка та впровадження гнучких навчальних планів, побудова системи зворотного зв'язку з роботодавцями, офіційний облік надання послуг, ліцензування діяльності фахівців із фізичної реабілітації на державному рівні, поступовість і системність у виборі логіки викладання навчальних дисциплін, а також співпраця між навчальними закладами, закладами соціального забезпечення й закладами охорони здоров’я (Bazylchuk, 2017, 2019).

Відповідно до даних, що були наведені Спілкою фізіотерапевтів Чеської Республіки, професійна підготовка в університетах у зазначеній галузі триває від трьох до п’яти років (Liannoi, 2017). Поряд 3 медичними факультетами, підготовку бакалаврів i магістрів із фізіотерапії здійснюють факультети фізичного виховання та спорту.

Специфіка системи вищої освіти в Австрії полягає в тому, що студентам надається повна самостійність у формуванні розкладу, виборі предметів, викладачів, екзаменаторів, тематики та програм дослідницьких проєктів. Тривалість програми також не $\epsilon$ суворо регламентованою. Програму, що розрахована на 3 роки навчання, студент може засвоїти протягом 4-4,5 років, не маючи академічної заборгованості. Магістерські програми підготовки фахівців в Австрії призначені для тих, хто прагне вдосконалювати здобуті знання в певній вузькій спеціальності. 
Тривалість таких програм, зазвичай, становить 2 роки (4 семестри, 120 кредитів ECTS). Академічні програми такого типу діють в усіх австрійських університетах та більшості місцевих вищих спеціальних шкіл. Аналіз змісту навчальних дисциплін засвідчив, що їхнє засвоєння сприяє формуванню у бакалаврів фізичної терапії технічних, методологічних, соціальнокомунікативних і дослідницьких навичок, що дають можливість застосовувати здобуті знання в галузі фізичної терапії під час доклінічної та клінічної практики, а також у процесі викладацької діяльності в поєднанні зі знаннями з педагогіки, дидактики, психології, соціології тощо (Liannoi, 2015, 2017).

Аналіз навчальних планів дав змогу виявити перелік біологічних дисциплін, що вивчаються здобувачами вищої освіти Австрії: перший семестр «Анатомія опорно-рухового апарату» (1,5 кредиту), «Топографічна анатомія» (1,5 кредиту), «Основи фізіології» (3 кредити), «Гігієна» (1 кредит), «Фізика і вступ до біомеханіки» (2 кредити), «Структура і функції кардіореспіраторної системи» (2 кредити); другий семестр - «Прикладні базові знання про системи органів» (1,5 кредиту), «Фізіологія стресу та теорії навчання» (2,5 кредиту), «Біомеханіка» (1 кредит), «Фізіологія м’язової системи» (2 кредити), «Структура і функції нервової системи» (2 кредити); третій семестр - «Прикладні принципи навчання про системи організму» (1,5 кредиту), «Фізіологія сенсомоторних рухів» (0,5 кредиту); четвертий семестр - домінують спеціальні предмети, такі як «Фізична терапія у психіатрії», «Фізична терапія у працетерапії», «Фізична терапія лімфатичної системи», «Фізична терапія нейродинаміки», «Фізична терапія опорно-рухового апарату», які є інтегрованими за своєю структурою та спрямуванням; п’ятий семестр - традиційно викладаються спеціальні предмети з реабілітаційною спрямованістю за медичними напрямами («Фізична терапія в онкології, реанімації та паліативній терапії», «Фізична терапія у педіатрії», «Фізична терапія в урології, гінекології й акушерстві»), які також $\epsilon$ інтегрованими; шостий семестр - вивчаються професійно спрямовані дисципліни соціально-економічного напряму («Основи етики», «Вирішення клінічних проблем», «Економіка охорони здоров'я», «Основи управління проєктами», «Сучасний ринок охорони здоров'я», «Юриспруденція») (Ofitsinyi sait Avstriiskoho universytetu prykladnykh nauk Yoanneum, 2021).

Отже, з позиції завдань авторського дослідження варто зазначити, що дисципліни природничого циклу вивчаються в австрійських закладах вищої освіти переважно на бакалаврському рівні у I-III семестрах і є підгрунтям для вивчення професійно орієнтованих дисциплін. Під час підготовки магістрів природничі дисципліни не вивчаються. Спочатку майбутні магістри вивчають загальні модулі щодо управління освітою та охороною здоров'я, організації досліджень, клінічної експертизи, а після цього відбувається закріплення 
управлінських якостей, клінічного досвіду, визначення тематики наукової роботи та розширення медичних знань. На завершення вивчаються додаткові предмети професійного спрямування і здійснюється підготовка магістерської дисертації (Ofitsiinyi sait Universytetu prykladnykh nauk Kampus Vena, 2021).

Ю. Лянной зазначає, що кількість навчальних курсів підготовки бакалавра фізичної терапії у закладах вищої освіти Австрії протягом семестру становить в середньому 14 дисциплін. Дисципліни соціально-гуманітарної підготовки складають 20 \%, дисципліни фундаментальної та загальноекономічної підготовки - 30 \%, а дисципліни професійної й практичної підготовки - 50 \%. Тривалість стажування майбутніх бакалаврів фізичної терапії становить 12901410 год. Водночас, студенти можуть проходити стажування щосеместра, починаючи з II-III семестрів навчання, або тільки на останньому курсі.

Результати аналізу навчальних планів магістратури, отримані Ю. Лянним, свідчать про те, що кількість навчальних курсів підготовки магістра з фізичної терапії в Австрії в середньому становить 10 дисциплін на семестр. Дисципліни доклінічної підготовки нараховують 15 \% від загальної кількості навчальних годин, дисципліни науково-дослідної підготовки - 16,5 \%, а дисципліни професійної та практичної підготовки - 60 \%. Стажування (клінічне навчання) майбутніх магістрів наук із фізичної терапії триває 330 год. (Liannoi, 2015, 2017).

Аналіз «Базового навчального плану канадських освітніх програм із фізичної терапії», який є орієнтиром для закладів вищої освіти в Канаді, засвідчив, що підготовка бакалаврів фізіотерапії здійснюється за безперервною 36-місячною програмою, яка включає 120 кредитів i п’ять блоків фундаментальних та спеціальних дисциплін, а також 1000 годин клінічної практики. Клінічна практика складається з п’яти блоків: терапія, терапія опорнорухового апарату, кінезіологія, кардіореспіраторна практика й неврологічна практика. Підсумковий контроль у закладах вищої освіти Канади передбачає проведення екзамену для визначення компетенції у галузі фізичної терапії, що складається із двох частин: письмової, що має назву «Кваліфікаційний екзамен», і практичної, яка називається «Національний екзамен із фізичної терапії».

3 позиції завдань авторського дослідження, важливим є поділ дисциплін «Базового навчального плану канадських освітніх програм із фізичної терапії» на такі групи: біологічні науки («Анатомія», «Фізіологія», «Гігієна», «Патологія», «Патофізіологія», «Біохімія», «Екологія»); дисципліни прикладного спрямування («Віковий розвиток людини», «Фізична працездатність людини», «Біомеханіка», «Кінезіологія»); дисципліни клінічного спрямування («Фізична та функціональна фармакологія»); дисципліни психосоціального спрямування («Психологія», «Соціологія», «Культурна антропологія»); дисципліни циклу професіоналізму та етики («Політика охорони 
здоров’я», «Управління», «Законодавство та регулювання»; «Міждисциплінарна практика»); методи наукових досліджень («Дослідження». «Статистика»); навчальна практика («Клінічне навчання»).

Шляхом аналізу інтернет-ресурсів було встановлено, що Університет Західного Онтаріо (University of Western Ontario) пропонує навчання на факультеті наук про здоров'я за декількома комбінованими клінічними програмами, які передбачають вивчення фізіотерапії, працетерапії та аудіології (Ofitsiinyi sait Universytetu Zakhidnoho Ontario, 2021; Description of physiotherapy in Canada, 2021). Програма передбачає також здійснення досліджень, що сприяють формуванню теоретичних і практичних знань про здоров'я й реабілітацію на межі інших дисциплін із врахуванням наукових інтересів студентів. Головні напрями таких досліджень охоплюють: здоров'я та старіння, здоров'я у професійній сфері, зміцнення здоров'я, професійну науку, фізіотерапію, реабілітаційну й логопедичну науки (Liannoi, 2017).

До 2001 року у США спеціальність фізіотерапія належала до навколомедичних або парамедичних спеціальностей. Фізіотерапію вивчали на другому ступені освіти - «магістр», а головною вимогою до підготовки абітурієнта була наявність документа про завершення першого (бакалаврського) ступеня підготовки з будь-якої спеціальності. Починаючи 32001 року, Американська асоціація фізіотерапії розробила та впровадила на загальнодержавному рівні освітню систему, яка передбачала семирічну програму навчання з кінцевим отриманням ступеня доктора фізіотерапії.

Пропонована система була побудована аналогічно до будь-якої медичної спеціальності. Підкреслимо, що система медичної підготовки в США дещо відрізняється від подібних програм підготовки в інших країнах. Так, випускники американських середніх шкіл не можуть подавати заявки до медичних закладів вищої освіти, оскільки для цього вони повинні спочатку пройти чотирирічний курс навчання в коледжах за програмами, що складаються з курсів з органічної і неорганічної хімії, біології, математики, фізики, психології та суспільних наук. Лише в результаті завершення попереднього навчання за такою чотирирічною програмою випускники отримують можливість вступати до медичних закладів вищої освіти США (Liannoi, 2017).

Як зазначає Ю. Лянной, дисципліни в закладах вищої освіти США спрямовані на реалізацію п'яти основних напрямів: вирішення проблем, критичне прийняття рішень, проходження фізіотерапевтичної практики, діяльність у галузі охорони здоров'я та охорони навколишнього середовища, врахування індивідуально орієнтованого підходу для прийняття клінічних рішень. На вивчення фундаментальних дисциплін відводиться 22 \% від загальної кількості кредитів, дисципліни клінічної професійної підготовки становлять 
50 \%, прикладні дисципліни - 11 \%, клінічна освіта (практика) становить 17 \% і триває 34 тижні (Liannoi, 2017).

У закладах вищої освіти вивчаються такі дисципліни природничонаукового спрямування, як-от: «Анатомія кістково-м'язової системи», «Фізіологічні системи», «Механіка ходьби людини», «Аналітична анатомія», «Клінічна біомеханіка». Ці дисципліни вивчаються виключно на першому році навчання, мають інтегрований і практично орієнтований характер. Клінічна практика спрямована на удосконалення таких умінь та навичок: практичне й клінічне мислення практиканта, розпізнавання моделей клінічних ситуацій, застосування диференціальної діагностики, формування цілей і прогнозування, розробка плану лікування, комплексне управління пацієнтом, міжпрофесійна комунікація.

Як зазначає Ю. Лянной, після завершення навчання фізичні терапевти в США реалізують свої професійні навички в таких закладах та установах: лікарні, центри реабілітації, корпоративні або промислові центри здоров'я, приватні офіси, науково-дослідні установи, школи, коледжі й університети, дитячі центри, будинки для людей похилого віку, спортивні комплекси (Liannoi, 2017).

Навчальні плани для підготовки бакалаврів із фізичної терапії в закладах вищої освіти Нідерландів становлять 240 кредитів і розраховані на чотири роки навчання. У результаті пройденого навчання здобувачі проходять виробничий тест зайнятості (ABP), який дає змогу перевірити рівень їх знань, умінь і навичок проведення діагностичного й терапевтичного процесу. Окрім того, два рази на рік майбутні фахівці проходять такі види оцінювання: оцінювання концептуальних знань на основі письмового практичного тестування (НОC); іспити прикладного характеру для перевірки знань, необхідних для виконання складних професійних завдань (Liannoi, 2017).

У більшості Університетів Австралії створено Школи медичних наук (Тhe Schools of Health Sciences), які здійснюють набір на навчання кандидатів, що планують отримати ступінь магістра наук із реабілітації. Претенденти на вступ на здобуття ступеня магістра наук із реабілітації мають мати ступінь бакалавра із однісї з таких спеціальностей: фізіотерапія, медицина, фізкультурні науки, працетерапія, педіатрія, догляд за хворими. Окрім цього, претенденти мають мати не менше двох років стажу за відповідною професією, а також пройти співбесіду й письмове тестування, продемонструвавши знання англійської мови на рівні університетських аспірантських курсів (Liannoi, 2017). В університетах Австралії здійснюється підготовка магістрів наук із реабілітації, фізіотерапії та реабілітаційного консультування.

Узагальнення досвіду світової підготовки засвідчує, що в 20 країнах світу сьогодні використовують термін «фізіотерапія». До таких країн належать: 
Австрія, Велика Британія, Греція, Данія, Естонія, Ірландія, Іспанія, Італія, Латвія, Ліхтенштейн, Нідерладни, Німеччина, Норвегія, Польща, Португалія, Словенія, Туреччина, Фінляндія, Чехія та Швейцарія. Ще п’ять країн (Бельгія, Болгарія, Люксембург, Румунія й Франція) використовують термін «кінезітерапія». Терміном «фізична терапія» послуговуються Сербія, Україна, Хорватія та Чорногорія, а терміном «лікувальна гімнастика» - Ісландія, Угорщина й Швеція.

Як наслідок, аналіз результатів наукового пошуку дав змогу виявити такі тенденції підготовки фахівців з фізичної терапії у зарубіжних країнах:

- професійна діяльність фізіотерапевтів у більшості зарубіжних країн належить до компетенції галузі охорони здоров'я;

- у найтиповіших випадках перший цикл навчального ступеня (бакалавр фізіотерапії) має як мінімум 180 кредитів ECTS, а другий (магістр фізіотерапії) 120 кредитів ECTS, що відображає найбільш розповсюджений розподіл навчального часу для двох ступенів згідно з Болонською декларацією;

- у зарубіжній системі підготовки фахівців фізіотерапії наявна орієнтація на самостійну роботу здобувачів щодо підвищення дослідницького складника підготовки, особливо на рівні магістра;

- динаміка та постійна модернізація сучасних технологій навчання на рівні аудиторної роботи і діяльності в навчальних лабораторіях;

- наближення практичної підготовки до реальних умов майбутньої професійної діяльності, зокрема, практика з реальними пацієнтами;

- постійне накопичення досвіду роботи в мультидисциплінарній команді та впровадження супервізії у підготовку фахівців фізичної терапії;

- представлення найбільш широкого переліку предметів природничого циклу в системі вищої освіти Ізраїлю;

- на відміну від українських програм, у більшості країн дисципліни соціально-гуманітарного циклу вивчаються на старших курсах і спрямовані на оптимізацію професійно-адаптивного складника підготовки (особливо простежується при аналізі навчальних планів австрійських закладів);

- високий рівень інтеграції навчальних предметів, об'єднання їх у цикли та модулі, наскрізне вивчення проблематики (Австрія, Велика Британія);

- значна увага приділяється вивченню законодавства в сфері діяльності фізіотерапевта (Канада, США);

- виключно медична спрямованість спеціальності у США з необхідною попередньою підготовкою з природничонаукових дисциплін;

- переважання виробничих клінічних практик (Польща, Чехія, Велика Британія); 
- підтримка інноваційних підходів до розробки програм практичного професійного навчання та впровадження їх в освітній процес;

- широке впровадження міждисциплінарного підходу, що передбачає співпрацю студентів-реабілітологів із фахівцями з інших, суміжних з фізичною терапією, спеціальностей.

Обговорення. 3'ясовано, що найменування спеціальностей відрізняється в різних країнах (фізична терапія, фізіотерапія, реабілітація тощо), водночас, спрямування професійної діяльності фахівців у галузі фізичної реабілітації залишається на відновленні рухових функцій в осіб різних нозологій і різних категорій населення за допомогою фізичних засобів та методів. Установлено, що сфера професійної спрямованості фахівців із фізичної терапії також передбачає консультативну, дослідницьку, викладацьку діяльності.

Висновки. Отже, проведене дослідження дозволяє стверджувати, що спеціальності, відповідно до яких формується підготовка бакалаврів і магістрів із фізичної реабілітації, $є$ парамедичними й належать до галузі охорони здоров'я. Встановлено, що міжнародний класифікатор професій ISCO-08 містить спеціальність «фізіотерапевт», що має код 2264 і внесена в частину 226 «нші спеціалісти охорони здоров'я». Водночас, у країнах СС, США та Канаді зазначену спеціальність не відносять до лікарських, про що свідчить ії чітке відображення в Міжнародному класифікаторі професій ISCO-08.

\section{ЛІТЕРАТУРА:}

Базильчук О. В. Теоретичні і методичні засади професійної підготовки майбутніх фахівців 3 фізичної терапії, ерготерапії до роботи з відновлення здоров'я спортсменів: дис. ... докт. пед. наук: 13.00.04 / Хмельницький національний університет. Хмельницький, 2019. $600 \mathrm{c}$.

Базильчук О. В., Базильчук В. Б. Ізраїльський досвід професійної підготовки майбутніх фахівців з фізичної терапії у вищих навчальних закладах. Наукові записки Бердянського державного педагогічного університету. Серія: Педагогічні науки. 2017. Вип. 3. С. 8793.

Бєлікова Н.О. Основні аспекти професійної підготовки майбутніх фахівців з фізичної реабілітації у Польщі. Педагогіка, психологія та медико-біологічні проблеми фізичного виховання і спорту. 2010. № 3. С. 7-10.

Бєлікова Н.О. Структура та зміст підготовки фахівців з фізичної реабілітації в окремих країнах Європи. Збірник наукових пращь Уманського державного педагогічного університету імені П. Тичини. 2010. № 1. С. 19-26.

Герцик А.М. До питань тлумачення основних термінів галузі фізичної реабілітації: фізичний реабілітолог чи фізичний терапевт? Бюлетень Украӥнської асоиіації фахівців з фізичної реабілітащиї. 2010. Вип. 3. С. 1-4.

Герцик А.М. Можливості використання в Україні канадського досвіду організації клінічної діяльності фахівця фізичної реабілітації. Педагогіка, психологія та медико-біологічні проблеми фізичного виховання і спорту. 2004. Вип. 7. С. 27-35.

Гук С. Професійна підготовка фахівців 3 фізичної реабілітації в університетах Великої Британії: автореф. дис. ... канд. пед. наук: 13.00.04. Кам'янець-Подільський, 2015. 23 с. 
Копочинська Ю. Зміст професійної підготовки майбутніх фахівців з фізичної терапії у Великій Британії. Фізичне виховання, спорт і культура здоров'я у сучасному суспільстві. 2020. № 1(49). C. 21-28.

Лянной Ю. О. Зміст професійної підготовки фахівців з фізичної реабілітації (фізичної терапії) у вищих навчальних закладах Австрії. Педагогічні науки: теорія, історія, інноваційні технології. 2015. № 4(48). С. 74-87.

Лянной Ю. О. Теоретичні і методичні засади професійної підготовки майбутніх магістрів 3 фізичної реабілітації у вищих навчальних закладах: дис. ... докт. пед. наук: 13.00.04 / Національний педагогічний університет імені М.П. Драгоманова. К., 2017. 674 с.

Мордвінова I., Ольховик А. Підготовка студентів спеціальності «Фізична терапія» та «Ерготерапія» у країнах Європи. Педагогічні науки: теорія, історія, інноваційні технології. 2018. № 1(75). С. 152-161.

Освітні стандарти № 33. Фізіотерапія. URL: http://www.bip.nauka.gov. pl/bipmein/ (дата звернення: 17.03.2021).

Офіційний сайт Австрійського університету прикладних наук Йоаннеум. URL: www.fhjoanneum.at (дата звернення: 17.03.2021).

Офіційний сайт Університету Західного Онтаріo. URL: http://www.uwo.ca/ (дата звернення: 17.03.2021).

Офіційний сайт Університету прикладних наук Кампус Вена. URL: www.fh-campuswien.ac.at (дата звернення: 17.03.2021).

Фастівець А., Хоменко П., Шапаренко І. Концептуальні підходи до дослідження проблеми професійної підготовки фахівців з фізичної терапії. Wiadomosci Lekarskie. 2018. Т. LXXI, № 3(2). C. 781-786.

Description of physiotherapy in Canada.

URL: https://physiotherapy.ca/sites/default/files/site_documents/dopen-en.pdf (accessed date: 17.03 .2021$)$.

\section{REFERENCES:}

Bazylchuk, O.V. (2019). Teoretychni i metodychni zasady profesiinoi pidhotovky maibutnikh fakhivtsiv z fizychnoi terapii, erhoterapii do roboty $\mathrm{z}$ vidnovlennia zdorovia sportsmeniv [Theoretical and methodical aspects of professional training of future physical therapy, ergotherapy specialists for work with rehabilitation of sportsmen] (Doctoral dissertation, Khmelnytskyi National University, Khmelnytskyi, Ukraine). (in Ukrainian).

Bazylchuk, O. V. \& Bazylchuk, V. B. (2017). Izrailskyi dosvid profesiinoi pidhotovky maibutnikh fakhivtsiv z fizychnoi terapii u vyshchykh navchalnykh zakladakh. [The Israel experience in professional training of future specialists in physical therapy in higher educational establishments]. Scientific Works of BSPU. Series: Pedagogics, 3, 87-93 (in Ukrainian).

Bielikova, N. O. (2010). Osnovni aspekty profesiinoi pidhotovky maibutnikh fakhivtsiv z fizychnoi reabilitatsii u Polshchi Osnovni aspekty profesiinoi pidhotovky maibutnikh fakhivtsiv z fizychnoi reabilitatsii u Polshchi. [Basic aspects of professional training of future specialists in physical rehabilitation in Poland]. Pedagogics, Psychology, Medical-Biological Problems of Physical Training and Sports, 3, 7-10. (in Ukrainian).

Bielikova, N.O. (2010). Struktura ta zmist pidhotovky fakhivtsiv z fizychnoi reabilitatsii v okremykh krainakh Yevropy. [Structure and content of education of physical rehabilitation specialists in separate countries of Europe]. Collection of Scientific Papers of Uman State Pedagogical University, 1, 19-26. (in Ukrainian).

Description of physiotherapy in Canada. (2012). Retrieved from https://physiotherapy.ca/sites/default/files/site_documents/dopen-en.pdf.

Osvitni standarty № 33. Fizioterapiia. [Educational standards № 33. Physiotherapy]. (n.d.). Retrieved from http://www.bip.nauka.gov. pl/bipmein/.(in Ukrainian).

Fastivets, A., Khomenko, P., \& Shaparenko, I. (2018). Kontseptualni pidkhody do doslidzhennia problemy profesiinoi pidhotovky fakhivtsiv z fizychnoi terapii. [Conceptual approaches to the 
investigation of a problem of professional training of physical therapists]. Wiadomosci Lekarskie, LXXI(3/2), 781-786. (in Ukrainian).

Hertsyk, A. M. (2004). Mozhlyvosti vykorystannia v Ukraini kanadskoho dosvidu orhanizatsii klinichnoi diialnosti fakhivtsia fizychnoi reabilitatsii. [Opportunities of use of Canadian experience of organization of clinical work of physical rehabilitation specialists in Ukraine]. Pedagogics, Psychology, Medical-Biological Problems of Physical Training and Sports, 7, 27-35. (in Ukrainian).

Hertsyk, A.M. (2010). Do pytan tlumachennia osnovnykh terminiv haluzi fizychnoi reabilitatsii: fizychnyi reabilitoloh chy fizychnyi terapevt? [To the questions of interpretation of main terms in the field of physical rehabilitation: Rehabilitation therapist or physical therapist?]. Bulletin of Ukrainian Association of Physical Therapy Specialists, 3, 1-4. (in Ukrainian).

Huk, S. (2015). Професійна підготовка фахівців з фізичної реабілітації в університетах Великої Британіiі. [Professional training of physical therapy specialists at universities in Great Britain] (Candidate thesis, Kamianets-Podilskyi Ivan Ohiienko National University, Kamianets-Podilskyi, Ukraine). (in Ukrainian).

Kopochynska, Yu. (2020). Zmist profesiinoi pidhotovky maibutnikh fakhivtsiv z fizychnoi terapii u Velykii Brytanii. [Contents of professional training of future physical therapy specialists in the United Kingdom]. Physical Education, Sports and Health Culture in Modern Society, 1(49), 21-28. (in Ukrainian).

Liannoi, Yu. O. (2015). Zmist profesiinoi pidhotovky fakhivtsiv z fizychnoi reabilitatsii (fizychnoi terapii) u vyshchykh navchalnykh zakladakh Avstrii. [The content of training of the specialists in physical rehabilitation (physical therapy) in higher educational institutions in Austria]. Pedagogical sciences: Theory, History, Innovative Technologies, 4(48), 74-87. (in Ukrainian).

Liannoi, Yu.O. (2017). Teoretychni i metodychni zasady profesiinoi pidhotovky maibutnikh mahistriv z fizychnoi reabilitatsii u vyshchykh navchalnykh zakladakh. [Theoretical and methodical bases of professional training of future masters of physical rehabilitation at higher educational institutions] (Doctoral dissertation, National Pedagogical Dragomanov University, Kyiv, Ukraine). (in Ukrainian).

Mordvinova, I., \& Olkhovyk, A. (2018). Pidhotovka studentiv spetsialnosti «Fizychna terapiia» ta «Erhoterapiia» u krainakh Yevropy. [Preparation of students in specialty "Physical therapy" and "Ergotherapy" in countries of Europe]. Pedagogical Sciences: Theory, History, Innovative Technologies, 1(75), 152-161. (in Ukrainian).

Ofitsiinyi sait Universytetu prykladnykh nauk Kampus Vena. [Official website of Fachhochschule Campus Wien]. (n.d.). Retrieved from www.fh-campuswien.ac.at. (in Ukrainian).

Ofitsiinyi sait Avstriiskoho universytetu prykladnykh nauk Yoanneum. [Official website of University of Applied Sciences Joanneum]. (n.d.). Retrieved from www.fh-joanneum.at. (in Ukrainian).

Ofitsiinyi sait Universytetu Zakhidnoho Ontario. [Official website of University of Western Ontario]. (n.d.). Retrieved from http://www.uwo.ca/.(in Ukrainian).

\section{Інформація про авторів:}

Фастівець

Анна

Віталіївна:

http://orcid.org./0000-0001-6333-5519,

кандидат педагогічних наук, доцент, доцент кафедри соціально-гуманітарних дисциплін та фізичної терапії, ерготерапії Полтавського інституту бізнесу Міжнародного науково-технічного університету імені академіка Юрія Бугая, 36004, г. Полтава, вул. Чураївни 9, Україна

\section{Information about the authors:}

\section{Fastivets Anna Vitaliivna:}

http://orcid.org./ 0000-0001-6333-5519,
Associate Professor at the Department of Social

Sciences and Humanities and Physical Therapy, Ergotherapy Poltava Business Institute of Higher Educational Institution "Academician Y. Bugay International Scientific Technical University", Churaivny street, 9, Poltava, Ukraine 36004 
Цитуйте цю статтю як: Фастівець А. В. Світовий досвід підготовки фахівців фізіотерапії та ерготерапії. Теорія та методика навчання та виховання. 2021. № 51. С. 156-172.

DOI: $10.34142 / 23128046.2021 .51 .15$

Дата надходження статті до редакції: 14.09.2021

Стаття прийнята до друку: 5.10.2021 